\title{
Effects of neutralization of pregnant mares' serum gonadotrophin (PMSG) shortly before or at the preovulatory LH surge in PMSG-superovulated heifers on follicular function and development
}

\author{
P. L. A. M. Vos ${ }^{1}$, A. van der Schans ${ }^{2}$, A. A. C. de Wit ${ }^{2}$, \\ M. M. Bevers ${ }^{1}$, A. H. Willemse ${ }^{1}$ and S. J. Dieleman ${ }^{1}$ \\ ${ }^{\mathrm{I}}$ Department of Herd Health and Reproduction, Faculty of Veterinary Medicine, University of \\ Utrecht, Yalelaan 7, 3584 CL Utrecht, The Netherlands; and ${ }^{2}$ DLO Research Institute for \\ Animal Production (IVO-DLO) 'Schoonoord', 3700 AM Zeist, The Netherlands
}

\begin{abstract}
Normally cyclic heifers $(n=34)$ received 2500 iu pregnant mares' serum gonadotrophin (PMSG) i.m. at day 10 of oestrus, and $15 \mathrm{mg}$ prostaglandin (PG) i.m. at day 12 . Thereafter, a monoclonal antibody against PMSG was administered i.v. before $(n=24)$, at $(n=6)$ or shortly after $(n=4)$ the preovulatory LH surge. Peripheral blood concentrations of LH and oestradiol were compared; follicular development was monitored by daily ultrasound scanning; and the numbers of preovulatory-sized follicles and ovulations were counted $96 \mathrm{~h}$ after injection of PG following death. Anti-PMSG treatment before the LH surge inhibited the $\mathrm{LH}$ surge in 16 heifers $(67 \%)$. In these heifers, the initial increase in oestradiol concentration upon PMSG stimulation to $167.5 \pm 35.0 \mathrm{pmol}^{-1}$ was terminated immediately after anti-PMSG treatment and decreased rapidly to basal values, while the number of preovulatory-sized follicles remained constant until $68 \mathrm{~h}$ after PG injection; on average $0.4 \pm 0.1$ ovulations were counted. In the remaining eight heifers, five animals showed an immediate, but temporary, $20-60 \%$ drop in oestradiol concentration after anti-PMSG treatment. In all eight heifers $25 \%$ of the preovulatory-sized follicles ovulated. Treatment with anti-PMSG at or shortly after the LH surge did not affect the pattern of oestradiol concentration, but a significantly higher ovulation rate was observed in the animals treated shortly after the LH surge: $20.3 \pm 2.6$ versus $6.3 \pm 2.3$ in animals treated at the LH surge, which corresponded to $76 \%$ and $24 \%$ of the preovulatory-sized follicles monitored shortly before the period of multiple ovulations. Thus, neutralization of PMSG at any time before the maximum concentration of the preovulatory LH surge severely suppresses the functionality of the majority or all of the stimulated follicles, which is dependent on the time of injection of anti-PMSG. Although the follicles retain their size, they lose the potential to ovulate. It is concluded that interfollicular asynchrony of development is present at the time the $\mathrm{LH}$ surge occurs.
\end{abstract}

\section{Introduction}

Superovulation in cattle still produces rather variable results with respect to ovulation rate and yield of transferable embryos. In recent years pregnant mares' serum gonadotrophin (PMSG) superovulation procedures have included the administration of antibodies against PMSG around oestrus to suppress the adverse effects of residual PMSG by neutralizing it (Dhondt et al., 1978; Bouters et al., 1983). Administration of anti-PMSG shortly after the preovulatory LH surge that initiates final follicular and oocyte maturation improves the ovulation rate (Dieleman and Bevers, 1987) and the yield of transferable embryos (Dieleman et al., 1989).
In practice, however, accurate determination of when the preovulatory LH surge occurs is difficult. In the majority of trials, anti-PMSG was administered at fixed times in relation to the time of the injection of prostaglandin (PG) or in relation to behavioural signs of oestrus (for review, see Dieleman et al., 1993). When this method was used anti-PMSG was probably also administered before or at the time of the preovulatory $\mathrm{LH}$ peak as well as after this peak. In superovulated cows, the preovulatory LH peak occurs at intervals after injection of PG and onset of oestrus. These intervals vary considerably: 33-49 $\mathrm{h}$ (Bevers and Dieleman, 1987) after PG injection and $-9-32 \mathrm{~h}$ (Callesen et al., 1992) after onset of oestrus.

It is not clear what effect PMSG neutralization has shortly before or at the preovulatory LH surge on follicular function and development. Preliminary experiments (Vos et al., 1991) 
indicated a suppression of follicular function. Administration of anti-PMSG about $24 \mathrm{~h}$ after the injection of PG reduced the number of ovulations to between none and one per cow (Bouters et al., 1983; Saumande et al., 1984; Boryczko et al., 1992); this can be assumed to be well before the occurrence of the LH surge.

In this study, we investigated follicular function and development in PMSG-superovulated cattle after neutralization of PMSG before or shortly after the preovulatory LH surge.

\section{Materials and Methods}

\section{Experimental design}

The study was performed between December and April on 34 Dutch-Friesian heifers, which were housed indoors in groups of 4-5 animals under conditions which ensured normal ovarian cyclicity as described by Dieleman et al. (1983a). Experiments were started when at least one oestrous cycle was observed indoors. All animals were clinically examined and only heifers with a normal genital tract were selected. Progestagen ear implants (Crestar: Intervet International BV, Boxmeer) were applied to synchronize the oestrous cycle and were removed after 9 days. The heifers received 2500 iu PMSG i.m. (Folligon: Intervet International BV) on day 10 at $14: 00 \mathrm{~h}$, and $15 \mathrm{mg}$ PG i.m. (Prosolvin: Intervet International) $48 \mathrm{~h}$ later (day 12) (day 0: first day of first oestrus after removal of the ear implants).

Blood samples were collected from the jugular vein as described by Dieleman et al. (1983a) at 07:00 h once a day from day 1 until day 12 of the synchronized cycle, then every $2 \mathrm{~h}$ starting $\mathrm{I} \mathrm{h}$ before injection of PG until $91 \mathrm{~h}$ after PG injection.

Anti-PMSG (monoclonal 36A, Neutra-PMSG: Intervet International BV) was administered i.v. at a dose $(5 \mathrm{ml})$ sufficient to neutralize 2500 iu PMSG within $1 \mathrm{~h}$ (Dieleman and Bevers, 1987). The monoclonal anti-PMSG 36A possesses no binding affinity to bovine $\mathrm{LH}$ and $\mathrm{FSH}$, as no binding activity could be detected using this anti-PMSG with $\left.{ }^{125} \mathrm{I}\right]$-labelled highly purified bovine LH (bLH7981) and bovine FSH (bFSH HS-2-17). The first group of heifers $(n=9)$ was treated with anti-PMSG $24 \mathrm{~h}$ after the injection of PG. A second group consisting of 25 heifers was injected with anti-PMSG $36 \mathrm{~h}$ after PG injection to obtain animals treated with anti-PMSG shortly before, at, or shortly after the preovulatory LH surge. In PMSG-treated heifers the mean interval between PG injection and the maximum of the $\mathrm{LH}$ surge is $43.9 \pm 7.9 \mathrm{~h}$ (mean $\pm \mathrm{SD}$, $n=28$; range 33-49 h) (Bevers and Dieleman, 1987).

\section{Ultrasound scanning and collection of ovaries}

In all heifers $(n=34)$, the ovaries were examined using a real-time ultrasound scanner equipped with a $7.5 \mathrm{MHz}$ intrarectal linear array probe (Aloka, type SSD-248; Tokyo) to estimate the number and size of follicles in the categories: $2-5$, 5-8 and $>8 \mathrm{~mm}$; the category $>8 \mathrm{~mm}$ was defined as preovulatory-sized (Vos et al., 1990). Ultrasound scanning was carried out on day 10 before PMSG administration and at 20 , 44 and $68 \mathrm{~h}$ after PG injection. In general, multiple ovulations start $68 \mathrm{~h}$ after PG injection (Dieleman and Bevers, 1987).
The ovaries were recovered upon death $96 \mathrm{~h}$ after PG injection and the numbers of preovulatory-sized follicles and ovulations were counted.

\section{Radioimmunoassays}

Concentrations of progesterone and oestradiol were estimated by validated solid-phase ${ }^{125} \mathrm{I}$ radioimmunoassay methods (Coat-A-Count TKPG and TKE, respectively; Diagnostic Products Corporation, Los Angeles) as described by Dieleman and Bevers (1987). The sensitivity was $0.15 \mathrm{nmol}$ progesterone $\mathrm{I}^{-1}$ and $7.5 \mathrm{pmol}$ oestradiol $\mathrm{I}^{-1}$; the interassay coefficients of variation were $11 \%$ and $8.9 \%$, respectively.

Concentrations of $\mathrm{LH}$ were estimated by a validated radioimmunoassay method as described by Dieleman et al. (1983b, 1986). The intra- and interassay coefficients of variation were $<9 \%$. The sensitivity was $0.4 \mu \mathrm{g}$ NIH-LH-B4 $1^{-1}$. Crossreactivity of PMSG (highly purified PMSG PM23-2P; Intervet International) was $0.2 \%$.

All concentrations of PMSG were estimated in duplicate in one assay with a homologous double-antibody radioimmunoassay method as described by Dieleman and Bevers (1987). Before radioimmunoassay, samples were incubated with donkey anti-mouse antibody-coated cellulose suspension as described by Dieleman and Bevers (1987) to remove monoclonal antibody against PMSG and its complexes with PMSG. The lowest detectable amount of PMSG was $0.3 \mu \mathrm{g}^{-1}$ plasma; samples with a non-detectable concentration were arbitrarily assigned a value of $0.3 \mu \mathrm{g}^{-1}$. The intra-assay coefficient of variation was $7.1 \%$.

\section{Statistical analysis}

Differences between the means of samples were tested for significance by analysis of variance according to Scheffé (1959). $\chi^{2}$ analysis for heterogeneity was used to test the effect of time of treatment on the number of ovulations compared with the number of preovulatory-sized follicles. Data were considered to be significantly different at $P<0.05$.

\section{Results}

\section{Hormone concentrations}

On average the mean PMSG concentration increased from being undetectable before injection of PMSG to $8.25 \pm 0.44$ (SEM) $\mu \mathrm{g} \mathrm{l}^{-1}(n=34)$ on day 12 . The PMSG concentration decreased markedly by at least $85 \%$ within I h after the administration of anti-PMSG; the PMSG concentration was then already less than or equal to the detection limit of the radioimmunoassay method.

The mean progesterone concentration on day 10 (i.e. before PMSG administration) was $12.5 \pm 1.0 \mathrm{nmol} \mathrm{l}^{-1}(n=34)$, which increased to $22.5 \pm 1.5 \mathrm{nmol} l^{-1}$ by day 12 , i.e. before the injection of PG. Luteolysis was completed within $30 \mathrm{~h}$ after PG administration when the progesterone concentration was less than $3.2 \mathrm{nmol} \mathrm{l}^{-1}$. 


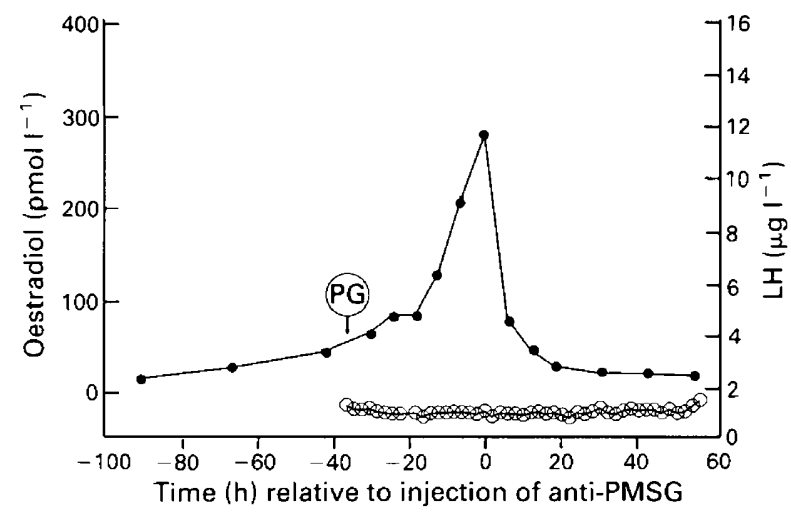

Fig. 1. Concentrations of $(\bigcirc)$ oestradiol and $(O) \mathrm{LH}$ in the peripheral blood of a heifer superovulated by pregnant mares' serum gonadotrophin (PMSG) treated with anti-PMSG $36 \mathrm{~h}$ after injection of prostaglandin (PG). No LH surge was observed.

Analysis of the LH concentrations showed a marked reduction in the number of heifers with a preovulatory $\mathrm{LH}$ surge. During the $92 \mathrm{~h}$ sampling period after the injection of PG an LH surge occurred in $18(53 \%)$ animals.

\section{Animals without $L H$ surge}

After the injection of anti-PMSG no LH surge was observed in seven of nine heifers treated $24 \mathrm{~h}$ after the injection of $P G$, and in nine of 25 heifers treated $36 \mathrm{~h}$ after PG injection.

In these heifers $(n=16)$ without an LH surge the oestradiol concentration increased from $11.9 \pm 0.6 \mathrm{pmol}^{-1}$ before PMSG administration to $167.5 \pm 35.0 \mathrm{pmol} \mathrm{l}^{-1}$ before antiPMSG administration, after which it decreased immediately. Within $5 \mathrm{~h}$, the oestradiol concentration dropped to $40 \%$ of the value before injection, and the concentration continued to decrease (Fig. 1).

The number of preovulatory-sized follicles increased significantly after PMSG treatment as observed by ultrasound scanning on day 10 and after the injection of PG (Table 1). Concurrently, the number of small follicles $(2-5 \mathrm{~mm})$ decreased significantly. Neutralization of PMSG did not decrease the number of preovulatory-sized follicles at 20 and $44 \mathrm{~h}$ after PG injection. Even at $68 \mathrm{~h}$ after PG administration the number of preovulatory-sized follicles remained constant. On average $14.4 \pm 3.4$ follicles $>8 \mathrm{~mm}$ and $0.4 \pm 0.1$ ovulations per heifer were counted $96 \mathrm{~h}$ after the injection of PG. In seven heifers of this group, one ovulation was observed in each animal.

\section{Animals with $L H$ surge}

An endogenous preovulatory LH surge was observed in two and 16 heifers treated with anti-PMSG 24 and $36 \mathrm{~h}$ after injection of PG, respectively. The animals treated at $36 \mathrm{~h}$ received the anti-PMSG injection before $(n=6)$, on $(n=6)$ or after $(n=4)$ the LH surge. The maximum concentration of the $\mathrm{LH}$ surge of these groups and the intervals between this maximum and the injection of PG and of anti-PMSG are shown (Table 2).
The oestradiol concentration increased from $14.1 \pm 1.9$ pmol $1^{-1}$ before PMSG administration to the high concentrations before anti-PMSG administration given in Table 3 . Injection of anti-PMSG before the LH surge ( $n=8$ animals) resulted, in five heifers, in a temporary $20-60 \%$ fall in oestradiol concentration immediately after treatment; in the other three animals, no temporary decrease was observed. In the animals treated with anti-PMSG on or after the LH surge, the oestradiol concentration decreased after the preovulatory $\mathrm{LH}$ surge (Fig. 2).

The animals treated with anti-PMSG either before, on or after the LH surge showed a similar distribution of the follicles over the three size categories on day 10 before the administration of PMSG. The number of small $(2-5 \mathrm{~mm})$ follicles was predominant over that of the 5-8 and $>8 \mathrm{~mm}$ categories; the averages were $22.2 \pm 1.8,2.0 \pm 0.6$ and $1.1 \pm 0.1 \quad(n=18)$, respectively. As in the heifers without an $\mathrm{LH}$ surge, the number of preovulatory-sized follicles significantly increased $20 \mathrm{~h}$ after the injection of PG concurrent with a decrease in the number of small follicles.

After neutralization of PMSG, ultrasound scanning $44 \mathrm{~h}$ after PG injection showed an increase in the number of preovulatory-sized follicles that was not significant; the numbers of the other size categories remained similar to those observed shortly before anti-PMSG treatment (Table 4). At about the time of multiple ovulations $68 \mathrm{~h}$ after injection of PG, the number of preovulatory-sized follicles decreased significantly only in the heifers treated with anti-PMSG after the LH surge. Accordingly, in this group the number of ovulations per heifer $(20.3 \pm 2.6)$ was significantly higher than that of heifers treated with anti-PMSG before the LH surge $(3.5 \pm 2.5$ and $7.3 \pm 2.5,24$ and $36 \mathrm{~h}$ after PG injection, respectively) or on the LH surge $(6.3 \pm 2.3)$. Although the numbers of preovulatory-sized follicles $44 \mathrm{~h}$ after PG injection were not significantly different for the heifers treated before or after the LH surge (Table 4), a difference in response to PMSG stimulation seemed to occur. The effects of this difference in response on the difference in the number of ovulations was avoided by performing $\chi^{2}$ analysis on the number of ovulations versus the number of preovulatory-sized follicles observed $44 \mathrm{~h}$ after PG injection. A significant effect of treatment with anti-PMSG before the maximum concentration of the preovulatory LH surge was found in comparison to heifers treated after this maximum was reached. The number of preovulatory-sized follicles observed by ultrasonography $68 \mathrm{~h}$ after PG injection (Table 4) was not significantly different from that counted upon death $96 \mathrm{~h}$ after PG injection for the heifers treated with anti-PMSG before $(20.0 \pm 0.0$ and $12.2 \pm 2.5,24$ and $36 \mathrm{~h}$ after PG injection, respectively), on $(20.8 \pm 4.3)$ or after $(9.7 \pm 1.0)$ the preovulatory LH surge.

\section{Discussion}

Injection of monoclonal anti-PMSG neutralized circulating PMSG immediately, as reported by Dieleman and Bevers (1987). This antibody can therefore be used to investigate the effects of deprivation of PMSG at specific times during the phase of follicular development preceding the maximum concentration of the preovulatory LH surge. 
Table 1. Number of follicles per size category as observed by ultrasound scanning at different times during superovulation in all heifers without the preovulatory LH surge upon administration of anti-pregnant mares' serum gonadotrophin (PMSG) 24 or $36 \mathrm{~h}$ after prostaglandin (PG) injection

\begin{tabular}{lcccc}
\hline & & \multicolumn{3}{c}{ Time $(\mathrm{h})$ after PG injection } \\
\cline { 3 - 5 } Follicle category $(\mathrm{mm})$ & Day 10 & 20 & 44 & 68 \\
\hline $2-5$ & & & & $6.6 \pm 0.9^{\mathrm{b}}$ \\
$5-8$ & $16.6 \pm 2.9^{\mathrm{a}}$ & $8.5 \pm 1.0^{\mathrm{b}}$ & $0.8^{\mathrm{b}}$ \\
$>8$ & $4.0 \pm 1.4$ & $9.7 \pm 1.6$ & $7.6 \pm 1.6$ & $7.8 \pm 1.5$ \\
& $1.4 \pm 0.2^{\mathrm{a}}$ & $8.8 \pm 2.2^{\mathrm{b}}$ & $14.0 \pm 2.5^{\mathrm{b}}$ & $12.5 \pm 2.6^{\mathrm{b}}$ \\
\hline
\end{tabular}

Values are means \pm SEM; number of heifers $=16$.

Values within a row with different superscripts are significantly different.

Follicles $>8 \mathrm{~mm}$ : preovulatory-sized follicles.

Table 2. Intervals and maximum concentration of the LH surge of heifers treated with pregnant mares' serum gonadotrophin (PMSG) and injected with anti-PMSG at 24 or $36 \mathrm{~h}$ after prostaglandin (PG) injection

\begin{tabular}{lccc}
\hline $\begin{array}{l}\text { Time of } \\
\text { anti-PMSG treatment }\end{array}$ & Interval PG - LH & Interval anti-PMSG - LH & $\begin{array}{c}\text { Maximum concentration } \\
\text { of the LH surge }\left(\mu g 1^{-1}\right)\end{array}$ \\
\hline $\begin{array}{l}24 \mathrm{~h} \text { after PG } \\
36 \text { h after PG: }\end{array}$ & $37.0 \pm 4.0(n=2)$ & $13.0 \pm 4.0$ & $6.8 \pm 1.1$ \\
Before LH surge & $44.3 \pm 1.1(n=6)$ & $8.3 \pm 1.1$ & $13.0 \pm 2.4$ \\
On LH surge & $38.7 \pm 0.3(n=6)$ & $2.7 \pm 0.3$ & $12.3 \pm 2.8$ \\
After LH surge & $32.5 \pm 1.3(n=4)$ & $-3.5 \pm 1.3$ & $12.1 \pm 1.7$ \\
\hline
\end{tabular}

Values are means \pm SEM.

$n=$ number of heifers.

Table 3. Oestradiol concentrations at specific times in the peripheral blood of heifers treated with pregnant mares' serum gonadotrophin (PMSG) and injected with anti-PMSG at 24 or $36 \mathrm{~h}$ after prostaglandin (PG) injection

\begin{tabular}{|c|c|c|c|}
\hline $\begin{array}{l}\text { Time of } \\
\text { anti-PMSG treatment }\end{array}$ & $\begin{array}{l}\text { Oestradiol concentration } 5 \mathrm{~h} \\
\text { before anti-PMSG treatment }\left(\mathrm{pmol} \mathrm{l}^{-1}\right)\end{array}$ & $\begin{array}{l}\text { Oestradiol concentration } 5 \mathrm{~h} \\
\text { after anti-PMSG treatment (pmol } \mathrm{I}^{-\mathrm{x}} \text { ) }\end{array}$ & $\begin{array}{l}\text { Oestradiol concentration at } \\
\text { LH peak }\left(\text { pmol l} l^{-1}\right)\end{array}$ \\
\hline $24 \mathrm{~h}$ after $P G$ & $235.3 \pm 47.7(n=2)$ & $116.3 \pm 63.9$ & $132.5 \pm 79.1$ \\
\hline \multicolumn{4}{|l|}{$36 \mathrm{~h}$ after PG: } \\
\hline Before LH surge & $219.3 \pm 80.0(n=6)$ & $197.6 \pm 84.4$ & $228.0 \pm 82.1$ \\
\hline On LH surge & $329.1 \pm 92.9(n=6)$ & $325.6 \pm 64.6$ & $346.9 \pm 85.8$ \\
\hline After LH surge & $488.8 \pm 112.9(n=4)$ & $259.2 \pm 90.7$ & $488.8 \pm 112.9$ \\
\hline
\end{tabular}

Values are means \pm SEM. $n=$ number of heifers.

Before the injection of anti-PMSG, the patterns in the peripheral blood of the concentrations of progesterone and oestradiol are generally in accordance with the patterns reported by Bevers and Dieleman (1987) for PMSG/PG-treated cows. The high oestradiol concentration can be attributed to the number of preovulatory-sized follicles (Bevers and Dieleman, 1987). After neutralization of PMSG, the preovulatory LH surge occurring in only $53 \%$ of the heifers displayed an amplitude and extent that were normal for PMSG/PGstimulated cows (Dieleman et al., 1989). In these animals, the oestradiol concentration decreased to basal values after the maximum concentration of the LH surge was reached, in agreement with studies by Dieleman and Bevers (1987), whereas in the heifers without an LH surge, the oestradiol concentration decreased rapidly, immediately after the antiPMSG treatment.

Administration of anti-PMSG $36 \mathrm{~h}$ after the injection of PG resulted in the treatment of heifers shortly before, at the ascending limb of the LH surge or after this surge, owing to normal variation in duration of the interval between injection of PG and the LH surge (Bevers and Dieleman, 1987; Callesen et al., 1992). As an inverse correlation has been reported between this interval and the number of preovulatory-sized follicles (Bevers and Dieleman, 1987), it could be expected that heifers treated with anti-PMSG before the LH surge would show a smaller response than would those treated after the 

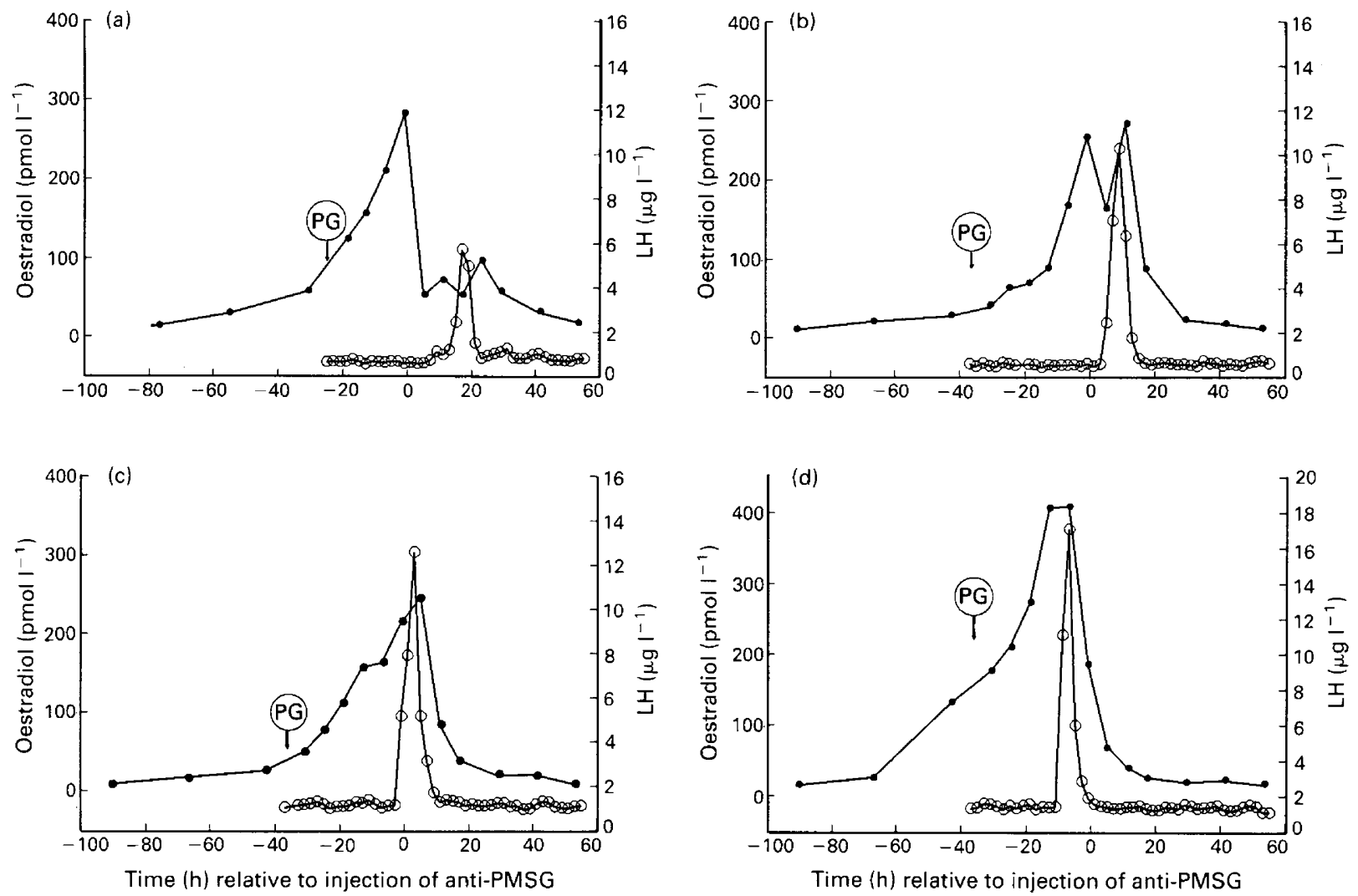

Fig. 2. Concentrations of $(-)$ oestradiol and $(O) \mathrm{LH}$ in the peripheral blood of heifers treated with pregnant mares' serum gonadotrophin (PMSG). The patterns are representative for heifers in which an LH surge was observed upon anti-PMSG treatment (a,b) before [24 and $36 \mathrm{~h}$ after prostaglandin (PG) injection, respectively], (c) on or (d) after the LH surge.

LH surge. However, no significant difference in the number of preovulatory-sized follicles was observed by ultrasound scanning $44 \mathrm{~h}$ after the injection of PG, although a tendency could be distinguished for which the difference in oestradiol concentration $5 \mathrm{~h}$ before injection of anti-PMSG is also indicative. Counting the number of follicles using transrectal ultrasound scanning is probably less accurate for ovaries containing numerous large follicles present before and after the LH surge in PMSG-treated heifers (Vos et al., 1992) than for ovaries during the unstimulated oestrous cycle (Pierson and Ginther, 1987). Nevertheless, ultrasound scanning clearly showed the stimulatory effect of PMSG treatment when the numbers of follicles in the three size categories were compared on day 10 and $20 \mathrm{~h}$ after the injection of PG.

Neutralization of PMSG before the eventual LH surge during the phase of selection and growth of follicles obviously suppressed the LH surge in most of the heifers in which no LH surge was detected. This group of animals comprised a markedly higher proportion $(67 \%)$ of the PMSG/PG-treated heifers than did the general $14-20 \%$ proportion of animals in which no LH surge occurs upon superovulation with PMSG/PG (Callesen et al., 1986; Dieleman et al., 1989). The usual hormonal mechanisms regulating the release of the preovulatory LH surge (Bevers et al., 1989) are probably inhibited in these animals owing to the rapid decrease in the oestradiol concentration immediately after the administration of anti-PMSG. Apparently, FSH-like support by PMSG is still required for follicular oestradiol production during the phase of development preceding the $\mathrm{LH}$ surge in a large proportion of animals treated for superovulation. Although it can be assumed that all stimulated follicles lose their functionality, they obviously do not undergo morphological regression until 32-44 h after injection of anti-PMSG (as observed by ultrasound scanning).

In the animals with a preovulatory LH surge, a temporary fall in the oestradiol concentration occurred immediately after the administration of anti-PMSG before the onset of the LH surge. A similar fall was not observed upon injection of anti-PMSG either at or after the LH surge. Probably, this drop was obscured by the normal decrease in the oestradiol concentration to basal values initiated by the preovulatory LH surge. The temporary fall may indicate that neutralization of PMSG affects the oestradiol production by all preovulatory-sized follicles. However, it is more likely that the oestradiol production is inhibited in only some of the preovulatory-sized follicles, which is similar to the process observed in the animals without an LH surge. The observed reduced number of ovulations in animals treated with anti-PMSG before the LH surge in comparison with that of animals treated after the surge supports this view. It is suggested that some of the preovulatory-sized follicles are less advanced and still require FSH-like support by PMSG shortly before the preovulatory LH surge at the end of the phase of selection and growth of follicular development. This indicates that there is interfollicular 
Table 4. Number of follicles per size category as observed by ultrasound scanning during superovulation in heifers with a preovulatory LH surge upon administration of anti-pregnant mares' serum gonadotrophin (PMSG) at 24 or $36 \mathrm{~h}$ after prostaglandin (PG) injection

\begin{tabular}{|c|c|c|c|c|}
\hline \multirow{2}{*}{$\begin{array}{l}\text { Time of anti-PMSG } \\
\text { treatment }\end{array}$} & \multirow[b]{2}{*}{ Follicle category (mm) } & \multicolumn{3}{|c|}{ Time (h) after PG injection } \\
\hline & & 20 & 44 & 68 \\
\hline $\begin{array}{l}24 \mathrm{~h} \text { after PG } \\
\quad(n=2)\end{array}$ & $\begin{array}{l}2-5 \\
5-8 \\
>8\end{array}$ & $\begin{array}{r}8.5 \pm 3.5 \\
20.0 \pm 5.0 \\
14.5 \pm 1.5^{\mathrm{a}}\end{array}$ & $\begin{array}{l}10.5 \pm 2.5 \\
16.0 \pm 5.0 \\
26.5 \pm 5.5^{\mathrm{a}}\end{array}$ & $\begin{array}{l}10.5 \pm 4.5 \\
14.0 \pm 4.0 \\
23.0 \pm 3.0^{\mathrm{a}}\end{array}$ \\
\hline $36 \mathrm{~h}$ after $\mathrm{PG}:$ & & & & \\
\hline $\begin{array}{l}\text { Before LH surge } \\
(n=6)\end{array}$ & $\begin{array}{l}2-5 \\
5-8 \\
>8\end{array}$ & $\begin{array}{l}12.2 \pm 0.3 \\
11.3 \pm 1.7 \\
11.3 \pm 3.2^{\mathrm{a}}\end{array}$ & $\begin{array}{c}8.5 \pm 1.0 \\
9.2 \pm 2.3 \\
19.7 \pm 4.9^{\mathrm{a}}\end{array}$ & $\begin{array}{c}9.5 \pm 1.3 \\
7.3 \pm 1.3 \\
16.8 \pm 5.6^{\mathrm{a}}\end{array}$ \\
\hline $\begin{array}{l}\text { On LH surge } \\
(n=6)\end{array}$ & $\begin{array}{l}2-5 \\
5-8 \\
>8\end{array}$ & $\begin{array}{c}9.3 \pm 1.0 \\
20.7 \pm 2.4 \\
11.2 \pm 7.2^{\mathrm{a}}\end{array}$ & $\begin{array}{c}8.8 \pm 1.3 \\
12.0 \pm 2.5 \\
29.0 \pm 7.5^{\mathrm{a}}\end{array}$ & $\begin{array}{c}8.3 \pm 0.8 \\
13.0 \pm 2.2 \\
20.2 \pm 7.1^{\mathrm{a}}\end{array}$ \\
\hline $\begin{array}{l}\text { After LH surge } \\
(n=4)\end{array}$ & $\begin{array}{l}2-5 \\
5-8 \\
>8\end{array}$ & $\begin{array}{r}8.5 \pm 1.3 \\
15.5 \pm 3.4 \\
25.0 \pm 3.7^{\mathrm{a}}\end{array}$ & $\begin{array}{r}8.3 \pm 2.3 \\
13.3 \pm 5.2 \\
34.0 \pm 4.3^{\mathrm{a}}\end{array}$ & $\begin{array}{r}8.8 \pm 1.3 \\
14.0 \pm 3.5 \\
6.3 \pm 2.3^{b}\end{array}$ \\
\hline
\end{tabular}

Values are means \pm SEM; $n=$ number of heifers; values within a row with different superscripts are significantly different; follicles $>8 \mathrm{~mm}$ : preovulatory-sized follicles.

asynchrony in the preovulatory follicular population. Evidently, interfollicular asynchrony is still present when the LH surge occurs.

Neutralization of PMSG at the ascending limb of the LH surge produced only 6.3 ovulations from the 29 preovulatorysized follicles, as observed $44 \mathrm{~h}$ after the injection of $\mathrm{PG}$, in comparison with the 20.3 ovulations in animals treated with anti-PMSG shortly after the maximum concentration of the LH surge. In PMSG/PG-treated heifers, multiple ovulations are generally completed $24-30 \mathrm{~h}$ after the maximum concentration of the LH surge (Dieleman and Bevers, 1987). It can therefore be assumed that the preovulatory-sized follicles observed by ultrasound scanning $68 \mathrm{~h}$ after the injection of PG will not have ovulated in the animals treated with anti-PMSG before, on or after the LH surge - as is also indicated by the number of ovulations in these animals. Moreover, the number of large follicles counted upon slaughter was not significantly different from that observed $68 \mathrm{~h}$ after PG injection.

It is possible that, upon superovulatory treatment, advanced follicles evoke the preovulatory $\mathrm{LH}$ surge, which occurs at too early a stage of development for the less advanced follicles. These less advanced follicles possibly do not react properly to the LH signal, which may lead to follicles that are abnormal a few hours before ovulation, either containing over four times higher oestradiol concentrations than those of the preovulatory follicle in non-stimulated heifers (Dieleman et al., 1983a, 1988) or showing discrepancies between follicular and oocyte maturational stage (de Loos et al., 1991; Hyttel et al., 1991).

In conclusion, administration of anti-PMSG at fixed times in relation to the injection of PG or to the onset of oestrus may produce rather variable results with regards to ovulation rate and embryo yield.
The authors thank S. H. J. Mook and J. H. M. Lutz and their assistants for tending the animais, D. M. Blankenstein, H. T. M. van Tol and A. V. P. van de Poll for technical assistance, Intervet International B.V., Boxmeer, The Netherlands for supplying Folligon, Neutra-PMSG and Prosolvin.

\section{References}

Bevers MM and Dieleman SJ (1987) Superovulation of cows with PMSG: variation in plasma concentrations of progesterone, oestradiol, LH, cortisol, prolactin and PMSG and in number of preovulatory follicles Animal Reproduction Science 15 37-52

Bevers MM, Dieleman SJ, van Tol HTM, Blankenstein DM and van den Broek J (1989) Changes in pulsatile secretion patterns of LH, FSH, progesterone, androstenedione and oestradiol in cows after superovulation with PMSG Journal of Reproduction and Fertility 87 745-754

Boryczko Z, Bostedt H and Hoffmann B (1992) Morphological and hormonal changes after superovulation in cows treated with Neutra-PMSG Proceedings of the 12th International Congress on Animal Reproduction The Hague Vol. 1 , 54 184-186

Bouters R, Moyaert I, Coryn M and Vandeplasche M (1983) The use of a PMSG antiserum in superovulated cattle: endocrinological changes and effects on timing of ovulation Zuchthygiene 18 172-177

Callesen H, Greve T and Hyttel P (1986) Preovulatory endocrinology and oocyte maturation in superovulated cattle Theriogenology 25 71-86

Callesen H, Bak A and Greve T (1992) Use of PMSG antiserum in superovulated cattle Theriogenology 38 959-968

de Loos FAM, Bevers MM, Dieleman SJ and Kruip ThAM (1991) Follicular and oocyte maturation in cows treated for superovulation Theriogenology 35 $537-546$

Dhondt D, Bouters R, Spincemaille J and Coryn M (1978) The control of superovulation in the bovine with a PMSG-antiserum Theriogenology 9 529-533

Dieleman SJ and Bevers MM (1987) Effects of monoclonal antibody against PMSG administered shortly after the preovulatory LH surge on time and number of ovulations in PMSG/PG-treated cows Joumal of Reproduction and Fertility 81 533-542 
Dieleman SJ, Kruip ThAM, Fontijne P, de Jong WHR and van der Weijden GC (1983a) Changes in oestradiol, progesterone and testosterone concentrations in follicular fluid and in micromorphology of preovulatory bovine follicles relative to the peak of luteinizing hormone Journal of Endocrinology 97 31-42

Dieleman SJ, Bevers MM, Poortman J and van Tol HTM (1983b) Steroid and pituitary hormone concentrations in the fluid of preovulatory bovine follicles relative to the peak of $\mathrm{LH}$ in the peripheral blood Journal of Reproduction and Fertility $69641-649$

Dieleman SJ, Bevers MM, van Tol HTM and Willemse AH (1986) Peripheral plasma concentrations of oestradiol, progesterone, cortisol, $\mathrm{LH}$ and prolactin during the oestrous cycle in the cow with emphasis on the peri-oestrous period Animal Reproduction Science 10 275-292

Dieleman SJ, Bevers MM, Kruip ThAM, van Tol HTM and Blankenstein DM (1988). Steroid profiles and micromorphology of the follicle population before ovulation in PMSG-superovulated cows with or without monoclonal anti-PMSG administered shortly after the preovulatory LH peak. Proceedings of the 11th International Congress on Animal Reproduction and Artificial Insemination, Dublin II 154 Abstract

Dieleman SJ, Bevers MM, Wurth YA, Gielen JTh and Willemse AH (1989) Improved embryo yield and conditions of donor ovaries in cows after PMSG superovulation with monoclonal anti-PMSG administered shortly after the preovulatory LH peak Theriogenology 31 473-487

Dieleman SJ, Bevers MM, Vos PLAM and de Loos FAM (1993) PMSG/antiPMSG in cattle: a simple and efficient superovulatory treatment? Theriogenology $3925-41$
Hyttel P, Callesen H, Greve T and Schmidt M (1991) Oocyte maturation and sperm transport in superovulated cattle Theriogenology 35 91-108

Pierson RA and Ginther OJ (1987) Follicular populations during the estrous cycle in heifers: I. Influence of day Animal Reproduction Science 14 165-176

Saumande J, Procureur R and Chupin D (1984) Effect of injection time of anti-PMSG antiserum on ovulation rate and quality of embryos in superovulated cows Theriogenology 21 727-731

Scheffé H (1959) The Analysis of Variance J Wiley, New York

Vos PLAM, de Loos FAM, Pieterse MP, Bevers MM, Taverne MAM and Dieleman SJ (1994) Evaluation of transvaginal ultrasound-guided follicle puncture to collect oocytes and follicular fluids at consecutive times relative to the preovulatory LH surge in eC6 P6-treated cows Theriogenology $\mathbf{4 1}$ 829-840

Vos PLAM, van der Schans A, de Wit AAC, Bevers MM and Dieleman SJ (1991) Effects of anti-PMSG administered before preovulatory LH surge on folliculogenesis in PMSG/PG-treated cows. Assisted Reproductive Technology and Andrology 2 150-151

Vos PLAM, Taverne MAM, Bevers MM, Dieleman SJ and de Loos FAM (1992) Monitoring of ovarian follicular development by ultrasound scanning and a histological validation of these observations in PMSG/PG-treated cows. Proceedings of the 8th Scientific Meeting of the Association Europeenne de Transfert Embryonnaire 230 (Abstract) Fondation M Merieux, Lyon, France 